\title{
DHARMA AND ADHARMA DIALOGUE BETWEEN THE PANDAWA AND WIRATA FIGURES IN THE KICAKA GEGURITAN TEXT
}

\author{
I Made Suastika and Luh Putu Puspawati \\ Faculty of Cultural Science \\ Universitas Udayana Denpasar \\ $<$ made.suastika57@yahoo.com>
}

\begin{abstract}
The epic tale of Mahabharata in the Old Javanese language contains various values, several of which are conveyed through its figures especially Pandawa and Korawa. The value of dharma is addressed through Pandawa who always has a quality of being good, honest, and courageous, with courteous behavior in speaking and actions. The Korawa figure more dominantly expresses adharma such as being less praiseworthy, coarse, with an evil disposition, wanting to dominate and get rid of his brothers on the Pandawa side, moreover even not hesitating to wish to kill them. The Kicaka Geguritan text in the Balinese language, from the Wirataparwa section of the Mahabharata, often reveals the value of dharma and adharma through the figures of Pandawa and from the Wirata kingdom. The author of the Kicaka Geguritan has a dialogue about these values when the figure of Pandawa is in a condition of suffering and alienates himself from the Wirata kingdom. In that episode, Pandawa receives less praiseworthy treatment and is hegemonized by the figures from the kingdom. Through the figure of Yudistira and others the teachings of dharma, also known as darma sadu, are expressed in their thought, speech, and action when dealing with other figures. Therefore, this paper will present the qualities of dharma and adharma as manifested by the figures in the Kicaka Geguritan while also showing that sasuluh awareness of dharma is conveyed through reading geguritan texts in Bali.
\end{abstract}

Keywords: dharma, adharma, Kicaka Geguritan

\section{Introduction}

Veda is a holy book of Hinduism that contains the sacred teachings of God (Ida Sang Hyang Widhi) consisting of: Reg Veda, Yayur Veda, Atarwa

$V e d a$, and Samaweda. There is another

fifth scripture in Hinduism called Bhagawadgita (Pancama Veda) which 
is part of the Book of Mahabharata namely Bhismaparwa in Old Javanese. It is one version of Bhagawadgita besides Sanskrit version.

In implementing the sacred teachings of the Vedas, it can include various ways of understanding such as the path of karma yoga (paths of activity, activity), the path of yoga (road of devotion), the path of jnana yoga (path of knowledge), the path of the raja yoga (path of meditation) so clearly expressed as a model of understanding of God (Ida Sang Hyang Widhi).

As the expression in Bhagawadgida "whichever way you go, I will receive". The meaning of this phrase can be explained in the Bhagawadgita Holy Scriptures as one of the foundations of life guidance in which it contains guidelines in all daily activities. The complexity of the written knowledge in the Vedas makes it the source of truth in religious life, there are various choices in context.

Truth in everyday life, called dharma, is the implementation of the teachings of the trilogy (the three frameworks of Hindu religion), tatwa (philosophy), etika and acara of Hinduism. Until now the implementation in the Hindu trilogy, still seems to run independently has not shown a togetherness, even one element is more dominant with others and vice versa. Sometimes the implementation of darma does not reflect tatwa (divinity) as well as the implementation of the acara does not dissertation tatwa, so also etika (ethics) is not accompanied by tatwa. Dharma (religious darma) which is contained in Scripture, as the essential truth.

When implementing the scriptures, through the Hindu religious trilogy: tatwa, susila, acara, through karma yoga as expressed in Bhagawadgita, a conversation between master and disciple, or dialogue between Krishna and Arjuna about the essence of the mind in the scriptures. Bhagawan Byasa, an author, rishi, muni, poet, compiler and creator of religious sacred teachings.

In Bhagawadgita there is a dialogue between Krishna and Arjuna, there is an outline of karma yoga dialogue, the way of worship by understanding the nature of God through action (work), without expecting a profit by way of peace of mind. Raja yoga to worship according to ability and consciousness of each, that is by way of yoga, by way of science of knowledge by way of meditation, by way of action of work. In the Bhagavagita it is affirmed that "whichever way is to be taken, karmic work is not carried out with a sin and performing the rituals and tapabrata should not be ignored (xviii, 3). Any action of action must be presented to the service of God as a karmaphala sacrament. In Bhagavadgita (V.71) "He who works to dedicate his work to the Brahman, without any motive of desire, is not touched by sin, like water slides 
on the lotus leaf."

Bhagawadgita is a holy book that talks about philosophy, the essence of Brahman, as well as the scripture of the darmasastra, that is the manual in doing right, the science that is always remembered to be used as the implementation/guidance of doing the right thing. This is according to Krishna's expression to Arjuna (in Bhagawadgita (IV.11) "whichever path a man takes towards me, all I receive from all of them all go to My way".

Therefore, the concept of Tri Framework of Hinduism, which consists of three which then make the guidance of life for Hindus in daily activities. When translated into more detailed implementation, such as tatwa (philosophy) can be translated into five concepts of pancasradha, the five basic beliefs, consisting of believing in Brahman (God), atman (spirit), punarbawa (rebirth) and moksa (freedom and union with God). In relation to the concept of moral (ethics), consisting of three, known as Tri Kaya Parisudha, three very sanctified behaviors, namely manacika (good thinking), wacika (good said) and kayika (good attitude). Acara (ceremonies/rituals) can be implemented into five yajnya (panca yajnya) consisting of dewa yajnya (offering/glorification to God), pitra yajnya (offering to the ancestors), rsi yajnya (offering/glorification to the saints/priests), manusa yajnya (glorification of human beings) and bhuta yajnya (sacrifice to spirits/ butakala) (interview, Jro Mangku, 2018).

\section{The Understanding of Darma Literature as the Implementation of the Hindu in Kicaka Geguritan Literature}

In a certain period there is implementation of understanding the value of religious scriptures that are continuously dialogues between teachers and students, such as dialogue swadarma between Krishna and Arjuna. Therefore, in the long period of understanding and implementation of the teachings of darma which is often called darma of religion or darma of literature is done by making literary works. The literary work in Bali is called geguritan, its content of darma is known as darma sastra. Relating to the meaning of literary darma can be explained as follows. The word darma (dharma (skt)) means: the established or affirmed, customary laws, customs, rules or conduct prescribed by custom, duty, justice, virtue, goodness, customs, religion, good works, law or doctrine of budhism, innate character, character, character (swabhawa). Nature, characteristic, efficacy, features. The other meanings are:

1. Rules of life and the attitude, established by the rules of God and passed on in religious law, law or code of obligation. There are the 
words a-dharma, knight-, lokika-, self-, ugra-.

2. Dharma as one of the nature of budhi, darma as law, justice, truth is associated Dewa Darma (Dharmawangsa-Yudistira)

3. Foundation related to religion, temple, monastery, hermitage (Zoemulder, 1995, 197). There is the word darmasastra (Zoemulder, 1995: 200), Book (teachings) about darma, there is dasasastra upadesa, textbook (doctrine) (Zoelmulder, 1995: 200)

As a model of understanding of darma in the days of Adiparwa the dialogue between Bhagawan Domia and his disciples, in the capacity to understand the darmasastra and the darma of religion. Described the understanding of religious teachings (salwir ning agama teles kahaji de sang uttangka) Here the dialogue tells about how a teacher (priest) can give knowledge based on the concept of guru pengajian and guru susrusa (sincerely faithful to the teacher), (Zoetmulder, 1991: 322) Explained in the text Bhagavan Domia teaches and gives teachings of darmasastra, sarwawidya, saha weda mantra nirang kesarwadayanan mwah kasidhiyan mantra pawehnira (Zoelmulder, 1999: 70).

The meaning of darma in Adiparwa means darma with all its aspects including the science of God, the devotion of a teacher and a disciple mentioned as swadarma (pangupajiwa) by a teacher and his disciple.

The storyline of Kicaka Geguritan, the characters tell by way of telling, when discussing darma, related to that sense of the tutur (words).

1. Memories, remembrance, consciousness, the depths of the soul, the deepest being (the deep mind), the place of absolute unity, the sacred tradition, smrti, (as opposed to sruti), the text contains religious doctrine, religious doctrine.

2. There are words (matutur), atutur, tunitur, kalukir, means remembering, being conscious and so on. (Zoelmulder, 1994: 307). Balinese speech (advice). (Warna, 1985)

Therefore, the style of speech used by the author of Geguritan Kicaka as mentioned above is by way of storytelling with a focus on the deepest, especially the conscience. Like Pihih Kicaka a ruler in Wirata who seduces Serandri (Drupadi) to accept his love. But Serandri refused it. The author express the bad attitude of Patih Kicaka, because Serandri has married the Pandavas. The Kicaka's text quote forced Serandri to come to his house. In the text as follow (bb.6)

"Inggih Sri Parameswarirya" - Oh your honour, the empress

"tulung titiang mamanah" - Please, I have a wish

"mopaja mangkin" - allow it now

"mangke ngidayang mapangguh" - to be able to meet

"Ni Serandri ring titiang" - Ni Serandri with me "masa kurang dolikan pacang mangutus" will less of feeling to delegates 
"mangde rawuh ke rumah titiang" - to bring her to my place

"punika mangkin bawasan" - it is now being discussed

Furthermore, the lengthy dialogue of the story is advices, to Patih Kicaka about hegemony and coercion for Serandri to accept his love with the harder way of chasing, strangling from behind, rape, kicking.

The author, through the character of Serandri, mention the nature character of Patih Kicaka is adarma (bad attitude), namely the existence of the five senses, the body becomes a source of disaster if not curbed, then the good and bad thoughts are well controlled. The mind as the determinant of action. The mind is closely related to deeds. Moreover, the existence of the five important senses understood, do not arise sadripu (six enemies). If the senses are obeyed never less then it will appear peteng pitu (darkness) like confused, loba, greedy, arrogant, evil appear also papa klesa. In the text as follows in stanza 5b.28.

\footnotetext{
"Antuk maraga" - Because of your status "uttama i gusti" - master, the main one "nenten nyandang" - it is inappropriate "sneng tken tityang" - to like me "tan patut wastan kayune" - the thought is inappropriate

"lelenjengan tan pangguh" - not finding the truth

"ngulurin karma tan yuku" - following bad behavior

"kandel kang papa klesa" - excessive sin and filth

"mwang lara kapangguh" - and find misery

"antuk laksana tan yogya" - because of inappropriate deeds

"ngapakrama" - deeds

"tuhu tan wring gati" - it does not make sense
}

"tan patiteng guh muka" - cannot hide your face

If craving, loba, arrogance is nurtured in human beings then transforms into peteng pitu and the senses are fully self-controlled, ultimately uncontrollable, on the contrary look for darma as the foundation of life, if as world leader. Take control and hold firmly (advice) to survive, not to see destruction. Master will get papa klesa (misery) if not hold darma. Only papa and desa are made then misery will be encountered. The following is in text 5b.27 - 28 .

"boya kadharmmane" - it is darma "patut ungsi" - which is worth searching for "ngamet jagat" - lead the world "patutang ring raga" - truth in self "kni patut pamarggine" - to be a true journey

"reh mawasta smara dudu" - because it is called a forbidden romance

"yaning ngrabining arabi" - if married to marry again

"nenten madrewe sukat" - has no rule "kangkat nulak tutur" - for refusing the advice

"ical kajana nuragane" - lost self-control "ring jagat" - in this world

"dadi jongkok keeng" - regretted by society "gumi ragane ngulah mabahan" - your kingdom will be destroyed

5b.28.

"Antuk maraga" - Because of your status "uttama i gusti" - master, the main one "nenten nyandang" - it is inappropriate "sneng tken tityang" - to like me "tan patut wastan kayune" - the thought is inappropriate

"lelenjengan tan pangguh" - not finding the truth

"ngulurin karma tan yuku" - following bad behavior

"kandel kang papa klesa" - excessive sin and filth

"mwang lara kapangguh" - and find misery 
"antuk laksana tan yogya" - Because of inappropriate deeds

"ngapakrama" - deeds

"tuhu tan wring gati" - it does not make sense

"tan patiteng guh muka" - Cannot hide your face

Serandri's counsel and affirmed by Dwijakangka (Yudhisthira) informs Patih Kicaka that the advice of darma and various obstacles and temptations has blanketed the mind of Patih Kicaka, yet he still rejects the doctrine of darma $s a d u$, he remains firmly saying and sure what he did to Serandri to propose and compel him, that becomes the desire, decree, and grace of Sang Hyang Asmara, Hyang Kama. Drupadi like tangible Goddess Uma Sruti, Goddess Moon (Sang Hyang Ratih).

Finally after Sang Yudhishthira advised on darma sadu with the control of mind, deeds and words, with the salvation and protection of the Hyang Surya, besides still leading to Sang Hyang Widhi (24) in order to keep away from bad and evil traits to keep the truth (ngrestitiang sane maraga patut), mangda presida sasuluh jagate sami, mecingak sane ala ayu nyusup, ring bawa sakala, niskala bhatara manuduh. Serandri then set the devotion to Sang Hyang Aditya, sawangian katur ring Ida Sang Hyang Surya, Sang Hyang Aditya matulung, will keep Srandri finally survived by running brata starch, sturdy please salvation, and free from the catastrophe of a Patih Kicaka.

\section{Conclusion}

Based on the above description can be described in conclusion as follows:

1. The Hindus Scriptures as truths (Sruti) revealed by Ida Sang Hyang Widhi (God) consist of $R g$ Veda, Sama Veda, Yayur Veda, Atarwa Veda. The fifth Vedic called Bhagawad Gita is a Sanskrit version and there is a version of Old Javanese that contains the Krsna and Arjuna dialogs in the Bhismaparwa Book.

2. In the implementation of religious life in its context there are various ways of understanding the doctrine/ vedic values as revealed in Bhagawadgita (iv.11), "whichever path is taken by me towards me, all-Ireceive, from everywhere they go My way“. One of the models of dialogue darma sastra (smrti) is contained in Adiparwa, about guru yaga and guru susrusa, in drawing knowledge for a student.

3. In fact, the Kicaka Geguritan in Balinese, the dialogue of darma is still done between good figures in running darma, to God and unfavorable character (adarma) and running sadripu even get the influence of pitu peteng. The style used in the dialogue is like the style of speech (advice).[] 


\section{References}

Gonda, J, 1936, Het Oud Javaansche Bhismaparwa, Bandung, AC Nix.Co

Pendit. Njoulon, S. 1995, Bhagawadgita, Jakarta: Hanoman Sakti (Edition I 1966)

Pigeaud, T,Th, 1981, Literatur of Java, Suplemen, Jilid IV : Leiden : Leiden University.

Puspawati Luh Putu, Sutama, Duana Sutika Nyoman, 2017, "Geguritan Kicaka, Analisis Struktur, Transliterasi Teks dan terjemahan" Fakultas Ilmu Budaya.

Radhakrisna, S. 2009, Bhagawadgita (Diindonesiakan oleh Yudhi Nurtanto), Yogyakarta : Irisod.

Suastika, I Made, 2017, "Dialog Krsna dan Arjuna tentang Swadarma Kesatria dalam Bhagawadgita berbahasa Jawa Kuna dalam Bhismaparwa, Jawa Kuna.

Suastika, Made, Jirnaya Ketut, Sukersa Wayan, Puspawati Luh Putu, 2016, Proses Pembalian Geguritan Yang Bersumber Pada Karya Sastra Mahabharata". Penelitian Grup Riset, Universitas Udayana.

Suastika, Made, Jirnaya Ketut, Sukersa Wayan, Puspawati Luh, 2017, "Proses Pembalian geguritan Kapiparwa yang Bersumber pada Karya Sastra Kakawin Ramayana,” Penelitian Grup Hibah, Universitas Udayana.

Zoetmulder P.J, 1982, Kamus Jawa Kuna - Indonesia, Jakarta, PT. Geramedia - Pustaka Utama (versi Inggris, 1982 ; versi Indonesia 1995)

Zoetmulder, P.J. 1994, Kalangwan: Sastra Jawa Kuna, Selayang Pandang, Jakarta: Djambatan. 